\title{
SEKSUALINIO SMURTO PRIEŽASČIŲ IR PREVENCIJOS ANALIZE்
}

\author{
Alisa Pozniak, Natalja Fatkulina \\ Vilniaus universiteto Medicinos fakulteto Sveikatos moksly institutas
}

\begin{abstract}
Raktažodžiai: seksualinio smurto priežastys, seksualinio smurto rizikos veiksniai, seksualinio smurto prevencija.
\end{abstract}

\begin{abstract}
Santrauka
Seksualinis smurtas yra rimta, sunkiai atpažįstama visuomenès problema, kuri turi itakos moteru fizinei, psichinei ir reprodukcinei sveikatai. Tokio pobūdžio agresija dažniausiai patiriama iš intymių partnerių ir daugeliu atvejų ją lydi psichologinis, ekonominis bei fizinis smurtas. Tai moterų pagrindinių teisių, susijusių su orumu bei lygybe, pažeidimas. Svarbu suprasti pagrindines lytinès prievartos priežastis, nes tik tokiu būdu galima sumažinti jos paplitimą. Darbo tikslas - išanalizuoti seksualinio smurto priežastis ir prevenciją, atsižvelgiant ị publikuotus mokslinius šaltinius. Literatūros šaltinių paieška buvo vykdoma naudojantis elektroninèmis duomenų bazèmis PubMed, Cochrane ir Google Scholar. İ sisteminę apžvalgą itraukti 39 straipsniai nagrinejjama tema. Rezultatai parodè, kad smurtas negali būti nulemtas vieno veiksnio - jo priežastys yra kompleksinès. Smurtautojams būdinga agresija, nemokèjimas spręsti konfliktų, impulsyvumas, auklëjimo spragos, vaikystės traumos. Aukos prisirišimas prie skriaudejo, noras jam padèti taip pat yra seksualinès prievartos priežastis. Siekiant sumažinti seksualinị smurtą, svarbi yra pirminè, antrinè ir tretinè smurto prevencija.
\end{abstract}

\section{Ivadas}

Seksualinis smurtas yra aktuali visuomenès problema, kuri daro neabejotiną itaką asmens fizinei, psichinei bei reprodukcinei sveikatai [1]. Toki smurtą patirti gali kiekvienas, nors dažniau aukomis tampa moterys [2]. Seksualinis smurtas apibrèžiamas kaip bet koks be sutikimo atliekamas lytinis aktas arba méginimas ji atlikti su kitu asmeniu be jos arba jo laisvai išreikšto sutikimo, naudojant prievartą, nepriklausomai nuo kaltininko ir aukos santykių pobūdžio, bet kokioje aplinkoje, įskaitant, bet neapsiribojant namais ir darbu. Toks smurtas gali pasireikšti nepageidaujamais seksualinio pobūdžio komentarais bei flirtavimu [3]. Seksualini smurtą dažnai lydi psichologinis, fizinis arba ekonominis smurtas [4].
2017 metais PSO paskelbti duomenys rodo, kad pasaulyje maždaug 1 iš 3 moterų savo gyvenime patyre fizinį ir (arba) seksualinį intymaus partnerio arba asmens, nesančio artimu partneriu, smurtą. Dažniau pasitaiko intymaus partnerio smurtas [5].

Remiantis 2014 metais Europos Sajungos pagrindiniu teisių agentūros (FRA) ES mastu atlikta apklausa, kurioje dalyvavo 42 tūkst. moterų iš 28 ES šalių, beveik kas ketvirta moteris Lietuvoje teige patyrusi vienos ar kitos rūšies smurtą, o nuo fizinio ar seksualinio partnerio smurto kenčia 24 proc. Lietuvos moterų [6].

Lietuvos Respublikos baudžiamojo kodekso 21 skyriuje išskiriami nusikaltimai ir baudžiamieji nusižengimai žmogaus seksualinio apsisprendimo laisvei ir neliečiamumui,

kurie baudžiami laisvès atèmimo bausme. Šiame kodekse seksualinis smurtas ịgauna ịvairias formas, tokias kaip išžaginimas, seksualinis prievartavimas, privertimas lytiškai santykiauti, seksualinis priekabiavimas [7]. Smurtautojai ne visada nubaudžiami, nes moterims yra sunku prisipažinti ir atvirai kalbèti apie patiriamą seksualinį smurtą. Daugeliu atvejų aukos nedrịsta kelti į viešumą savo istorijas, nesikreipia pagalbos ir palaikymo, nes jaučia gèdą, todèl tikimybè pakartotinai patirti seksualinį smurtą didejja.

Su smurtu prieš moteris yra susiję nemažai stereotipų, sunkinančių prevenciją, todėl norint išvengti seksualinio smurto atvejų, svarbu išsiaiškinti priežastis, socialinius bei individualius veiksnius, lemiančius tokio smurto pasireiškimą [8]. 2018 metais Žmogaus teisių stebejjimo instituto atliktas tyrimas parodè, kad Lietuvoje seksualinis smurtas yra viena mažiausiai atpažisstamų smurto artimoje aplinkoje prieš moteris formų [9].

Tyrimo tikslas - išanalizuoti seksualinio smurto priežastis ir prevenciją, atsižvelgiant ị publikuotus mokslinius šaltinius.

\section{Tyrimo medžiaga ir metodai}

Atlikta mokslinės literatūros apžvalga. Atrinkti straipsniai, kuriuose aprašomos seksualinio smurto priežastys ir prevencija. Mokslinès literatūros paieška buvo atlikta $\mathrm{Pu}-$ bMed, Cochrane, Google Scholar duomenų bazèse, nau- 
dojant raktinius žodžius ir jų derinius: seksualinio smurto priežastys, seksualinio smurto rizikos veiksniai, seksualinio smurto prevencija. Iš viso atrinktos ir išanalizuotos 39 publikacijos. Duomenų apdorojimui taikomas aprašomosios kokybinès turinio analizès metodas. Rezultatai sugrupuoti pagal esminius radinius.

\section{Tyrimo rezultatai ir jų aptarimas}

Individualios aukos ir smurtautojo savybès. Seksualini smurtą lemia daugelio veiksnių sąveika. Individuali patirtis ir biologiniai veiksniai gali sąlygoti, kad žmogus taps smurto auka arba skriaudejju [10]. Individualiems veiksniams priskiriama vaikystejje patirta nepriežiūra ir auklëjimo spragos, žema saviverte, polinkis ị agresiją, asocialūs asmenybės bruožai. Tokie asmenys gali būti pernelyg impulsyvūs, neturintys draugų, patiriantys depresiją, nerimo priepuolius [11]. Vieno arba abiejų partneriu probleminis alkoholio ar kitų psichoaktyviųjų medžiagų vartojimas didina seksualinio smurto riziką. Apsvaigęs žmogus tampa amoralus ir asocialus, atsiranda vertybinių orientacijų destrukcija, provokuojanti seksualinès agresijos proveržius [12]. Alkoholis gali susilpninti elgesio kontrolès gebejjimus ir paskatinti vyrą, kuris turi polinkị ị smurtavimą, elgtis ypač agresyviai [13]. Apsvaigimas trukdo sąmoningai sutikti arba nesutikti užsiimti seksualine veikla. Moterys, kurios patyrẻ lytinị smurtą būdamos neblaivios, rečiau apie tai praneša, nes joms yra neaišku, ar nusikaltimas tikrai ịvyko [14]. Alkoholio bei narkotikų vartojimas gali tapti ir seksualinès agresijos atvejų pasikartojimo priežastimi [15].

Smurtaujančių tèvų ịtaka. Didesnę riziką patirti seksualini smurtą turi tos moterys, kurios stebejjo arba patyré tokią prievartą vaikystėje [12]. $2015 \mathrm{~m}$. lapkričio mènesị vykusioje atviroje diskusijoje „Tvirta mergaite“ psichoterapeutas Eugenijus Laurinaitis pritare šiai nuomonei, sakydamas, kad moteris, prieš kurią buvo smurtaujama vaikysteje arba ji matė prievartą prieš motiną, užauga jau turèdama tam tikrų psichologinių problemų, kurios gali turèti ịtakos jos pačios smurtiniam elgesiui. Tai palieka skaudžias žymes visam tolesniam gyvenimui ir gali sudaryti sąlygas patirti seksualinę prievartą, ją kentèti ir bijoti kreiptis pagalbos. Mergaitès, matydamos kaip jų motinos nesipriešina tokiam elgesiui, pradeda manyti, kad taip gyventi yra normalu ir kad tokia moters padètis šeimoje yra teisinga $[10,16]$. Vaikų auginimas tokioje „toksiškoje aplinkoje“ kuria smurtą, nes tikimybè, kad berniukai, kurie stebi netinkamą bei žiauru elgesį su savo motina, suaugę patys smurtaus prieš savo intymias partneres, tik dideja $[17,18]$. Vyrų seksualinès agresijos riziką didina vaikysteje patirtas ar matytas smurtas, tèvo neturèjimas, todèl galima teigti, kad smurtautoju negimstama, juo tampama [19].
Tarpasmeniniai partnerių santykiai ir Stokholmo sindromas. Seksualinis smurtas gali būti tarpusavio konfliktų padarinys [20]. Atskirai galima išskirti nesutarimus, kurie kyla dèl pavydo bei neištikimybès, nes tai itin žemina vyrus bei skatina lytinę prievartą [21]. Konfliktų atvejais seksualinį smurtą dažnai lydi psichologinis smurtas. Jam būdingas žeminimas, draudimas bendrauti su artimaisiais ir pažįstamais, jausmų ignoravimas, persekiojimas darbe, grasinimas atimti vaikus. Aukai grasinama, siekiant parodyti savo galią ir kontroliuoti ją [22]. Stokholmo sindromo elementai pasireiškia, kai moteris prisiriša prie skriaudejo ir bando išspręsti tokius nesutarimus, paklusdamos ir prisitaikydamos prie tokio elgesio. Prievartos priežastis jos įžvelgia savo elgesyje, taip pateisindamos ir net gailedamos tokio asmens [23]. Auka vengia šeimos narių, draugų, atsisako bet kokios pagalbos, nes jaučiasi vienintelè, galinti padèti ir pakeisti partneri. Pasikartojantys seksualinio smurto atvejai tik sustiprina moters baimę ir bejejgiškumą [24].

Moters finansinė priklausomybė. Ekonominè priklausomybė nuo partnerio didina seksualinio smurto riziką [25]. Moteris praranda savigarbą ir tampa priklausoma nuo smurtautojo, nes neturi galimybès savarankiškai priimti finansinių sprendimų ir turèti nuosavų lèšų. Skriaudèjas gali visiškai ją kontroliuoti, versdamas prašyti pinigų savo reikmėms, atsisakydamas išlaikyti vaikus tiek santuokoje, tiek po skyrybų, trukdydamas įsidarbinti ar išsaugoti darbą [20]. Aukai gali trūkti pinigų būstui ir net maistui, ji viena negali išlaikyti savęs bei vaikų, todèl nepalieka seksualinę prievartą prieš ją naudojančio vyro [26]. Situacija yra itin problemiška, kai moteris neturi artimujų, giminių, draugų, pas kuriuos galètų prisiglausti, nuolatinio ir stabilaus darbo. Tokiu atveju ji bijo prieštarauti ir tiesiog paklūsta skriaudejjui, kuris toliau prievartauja, manipuliuoja partnere ir užkrauna jai visus buities ir vaiko priežiūros rūpesčius, ịsitikinęs, kad išnaudojama moteris vis tiek pasiliks su juo ir niekam apie tai nepraneš [27].

Visuomenès požiūris ir stigmatizacija. Visuomenèje egzistuoja daugybè mitų ir stereotipų, pateisinančių seksualinį smurtą prieš moteris. Vyrauja įsivaizdavimas, kad moterys yra fiziškai silpnos ir užima žemesnę poziciją socialinèje hierarchijoje [20]. Patriarchalinės nuostatos bei lyčių nelygybė remia bei stiprina žemesnę merginų padètị šeimoje, darbe bei visuomeneje, sustiprindamos vyrų dominavimą [28]. Manoma, kad moteris turi būti nuolanki, paklusni, stengtis itikti partneriui, nes yra pernelyg emocinga ir nesugeba priimti savarankiškų sprendimų. Tokie stereotipai pasitaiko tiek menkos žmogaus teisių apsaugos kultūros šalyse, tiek ir išsivysčiusiose Vakarų demokratijos šalyse [6]. Paplitę mitai, kad mergina, kuri pernelyg atvirai rengiasi, ryškiai dažosi, vartoja alkoholị ar kitas psichoaktyvias medžiagas, 
pati provokuoja išprievartavimą. Kartais klaidingai manoma, kad sutuoktinio arba partnerio seksualiné prievarta yra neimanoma. [29]. Moterys, patyrusios lytini smurtą, neretai kaltinamos, smerkiamos bei patiria stigmą, todèl nedrịsta pasakoti apie savo patirti šeimai, draugams ir nesikreipia specialistų pagalbos. Joms gèda dèl tokios padèties, nepadorių ịvykio detalių, bejègiškumo. Aukos, nesulaukusios užuojautos bei supratimo, išgyvena vienatvę ir nusivylimą [30]. Kartais merginoms, patyrusioms seksualinę prievartą, peršama mintis, kad po tokio įvykio jos nebus „tinkamos“ santuokai ir motinystei, todèl verčiau niekam apie tai nepasakoti. Seksualinio smurto atvejai tarp partneriu gali ir toliau kartotis, nes skriaudejai taip ir neatsako už savo veiksmus ir lieka nenubausti [31].

Pirminė prevencija. Pirminès prevencijos tikslas yra užkirsti kelią seksualinio smurto atsiradimui, šalinant jo priežastis ir rizikos veiksnius. Tai reiškia, kad turi būti kuriama sveika, saugi aplinka ir formuojamos elgesio normos, kurios padètų išvengti lytinès prievartos atvejų [32]. Prevencijos priemonès apima asmenini, tarpasmenini, bendruomenès ir visuomenès lygmenis. Individualiame lygyje turètų būti diegiami ịsitikinimai, prieštaraujantys bet kokiam smurtui. Asmenys, kurie tampa lytinès agresijos liudininkais, turi būti raginami nelikti abejingais ir netoleruoti tokio elgesio [18]. Pasitelkiant žiniasklaidą ir švietimą, gali būti vykdomos specialios programos, kurios apibrēžtų, kas yra saugūs pasimatymai, pagarbūs santykiai, kaip spręsti iškilusias problemas, konfliktus, stresines situacijas bei kontroliuoti savo emocijas. Programos padètų atpažinti netinkamą elgesị, supažindintų su lytinès prievartos rizikos veiksniais. Tokie mokymai galètų apsaugoti nuo seksualinio smurto ir išmokytų jo išvengti ankstyvoje stadijoje [33]. Kuriant santykius, labai svarbios yra prevencinès strategijos, nukreiptos ị tarpasmeninị lygmenị. Tai gali būti specialistų vizitai nuo ankstyvos vaikystės pas vaikus auginančias šeimas arba programos, orientuotos ị šeimą, emociškai stiprinančios tėvų ir partnerių santykius, gerinančios tėvystès ịgūdžius ir skatinančios psichologiškai sveiką vaikų brandą [34]. Bendruomenès lygio prevencijos tikslas yra nustatyti aplinkybes, lemiančias asmens tapimą auka arba smurtautoju bei sukurti saugią socialinę aplinką, kurioje žmonèms būtų parūpintos tinkamos sąlygos gyventi, mokytis ir dirbti. Ši prevencija gali būti vykdoma mokyklose, darbovietėse, rajonuose, sprendžiant gyventojų socialinès atskirties, skurdo problemas, mažinant prekybos alkoholiu vietų skaičių [31]. Visuomenès lygmeniu siekiama pakeisti kultūrinius vyrų ir moterų elgesio modelius, pagrịstus vienos lyties nevisavertiškumo ar pranašumo ideja. Visuomenè turi būti informuojama apie ekonomines ir socialines lyties pagrindu kylančias seksualinio smurto pasekmes. Svarbus yra ịstatymų, kurie stiprina lyčių lygybę, leidimas, žiniasklaidoje kuriamų stereotipų keitimas, vienodų švietimo ir įdarbinimo galimybių užtikrinimas [6].

Antrinė prevencija - tai visuma priemonių, kuriomis siekiama kuo anksčiau nustatyti ir sustabdyti seksualini smurtą. Seksualinės prievartos aukos ir jų artimieji labai retais atvejais sulaukia sisteminès pagalbos. Medicinos darbuotojams, socialiniams pedagogams, policijos pareigūnams trūksta bendrujų žinių, kaip atpažinti seksualinę agresiją patiriančią moterị. Savo srities profesionalai, iš kurių tikimasi palaikymo ir patarimo, ne visada yra informuoti, kaip suteikti sisteminę pagalbą aukai bei jos artimiesiems [35]. Dažnai specialistai vengia kalbèti smurto tema ir nežino, kaip reaguoti, kai moteris nori apie tai pranešti. Dalis darbuotoju prisipažįsta, kad jaučia bejejgiškumą bei nusivylimą, nes nori padėti, bet nèra apmokyti, kaip tinkamai tai padaryti. Dar mažiau dèmesio skiriama profesionaliam darbui su smurtautojais, todèl galètų būti vykdomos mokymo programos specialistams, kurios suteiktų ịgūdžių, kaip ịtarti seksualinę prievartą bei kuo greičiau pagelbèti aukai. Programų tikslas - pristatyti galimas seksualinio smurto apraiškas, priežastis bei sprendimo būdus [36]. Svarbu skatinti ir aukas kuo anksčiau prisipažinti apie patiriamą lytinę prievartą ir nebijoti visuomenès kritikos. Žinomų žmonių, savo gyvenime patyrusių seksualinị smurtą, ịtraukimas ị prevencines iniciatyvas gali padrąsinti garsiai kalbèti apie prievartą. 2017 metais pradètas „\#Me Too“ judejjimas atskleidè seksualinio priekabiavimo mastą. Izžymios moterys paviešino savo istorijas, suteikdamos smurto aukoms pasitikejjimo ir padidindamos jų sąmoningumą. Judèjimas išpopuliarejjo socialiniuose tinkluose, kur pasipyle prisipažinimai iš viso pasaulio. Skaudi patirtis suvienijo moteris ir paskatino nesitaikstyti su tokiu elgesiu [37].

Tretinė prevencija - tai gydomosios ir atkuriamosios priemonès, kuriomis bandoma sustabdyti prievartos progresavimą, sumažinti jos padarinius sveikatai ir gyvenimo kokybei [38]. Tretinès prevencijos tikslas yra išvengti reviktimizacijos. Didžiausias dèmesys skiriamas aukos reabilitacijai ir reintegracijai. Smurtą ir prievartą patiriančioms moterims būtina specializuota kompleksinè pagalba, apimanti jų psichologinị, teisinị bei socialinị informavimą, konsultavimą, palaikymą ir tarpininkavimą institucijose [35]. Pirmiausia turètų būti atliktas bendras sveikatos patikrinimas ir suteikta reikalinga medicininè pagalba. Neplanuotas néštumas, anoreksija, lytinių organų sužalojimai, lytiškai plintančios infekcijos yra dažnos ilgalaikio smurto pasekmès, kurios reikalauja neatidèliotinos pagalbos. Nukentejusioms merginoms reikalinga psichologine arba psichiatrinè pagalba, nes smurto atvejais didejja potrauminio streso sindromo, depresijos ir savižudybès rizika. Socialine reabilitacija ir reintegracija siekiama stiprinti aukos asmeninius ịgūdžius, pasitikèjimą savimi ir 
savo galimybėmis bei atpažinti netinkamą elgesị ankstyvoje stadijoje. Labai svarbu padèti moteriai nutolti nuo skriaudejo, suteikti jai reikalingą teisinę, finansinę pagalbą ir ịtikinti, kad bet koks smurtas yra visiškai nepriimtinas [4, 39].

\section{Išvados}

1. Smurtas negali būti nulemtas vieno veiksnio - jo priežastys yra kompleksinès.

2. Seksualinị smurtą lemia individualios žmogaus savybès. Smurtautojams būdinga agresija, nemokèjimas spręsti konfliktų, impulsyvumas, auklèjimo spragos. Psichoaktyviujų medžiagų vartojimas didina asocialaus elgesio tikimybę. Kita lytinès prievartos priežastis yra smurtaujantys tèvai. Vaikai, kurie patyrẻ arba stebėjo smurtą vaikysteje, panašiai elgsis užaugę.

3. Aukos prisirišimas prie skriaudejjo, noras padèti jam taip pat yra seksualinės prievartos priežastis. Dažnai moteris yra priklausoma nuo vyro tiek psichologiškai, tiek ekonomiškai, todèl išeiti tampa per sudetinga. Situaciją sunkina visuomenès sukurti mitai ir stereotipai, kurie pateisina smurtaujantị vyrą, bet smerkia ir kaltina auką. Dẻl tokio požiūrio merginos praranda pasitikejimą savimi ir nedrịsta prašyti pagalbos.

4. Pirminės arba ankstyvosios prevencijos tikslas yra šalinti seksualinio smurto priežastis ir rizikos veiksnius, skleidžiant informaciją ir šviečiant žmones. Antrine prevencija siekiama kuo anksčiau nustatyti lytinę agresiją ir neleisti jai progresuoti. Tretinè prevencija šalina lytinio smurto padarinius ir bando apsaugoti auką nuo reviktimizacijos.

\section{Literatūra}

1. Wamboldt A, Khan SR, Mellins CA, Hirsch JS. Friends, strangers, and bystanders: Informal practices of sexual assault intervention. Glob Public Health 2019;14(1):53-64.

https://doi.org/10.1080/17441692.2018.1472290

2. Wells D. Sexual violence interventions: considerations for humanitarian settings. Forensic Sci Int 2017;276:1-4. https://doi.org/10.1016/j.forsciint.2017.04.004

3 . World report on violence and health: chapter 6 . Sexual violence. 2002. https://www.who.int/violence injury prevention/violence/global_campaign/en/chap6.pdf?ua=1

4. Jina R, Thomas LS. Health consequences of sexual violence against women. Best Pract Res Clin Obstet Gynaecol 2013;27(1):15-26.

https://doi.org/10.1016/j.bpobgyn.2012.08.012

5. WHO. Violence against women, 2017.

https:/www.who.int/news-room/fact-sheets/detail/violenceagainst-women

6. Michailovič I. Violence against women as a form of sex discrimination and as a result of gender stereotypes. Informacijos mokslai, 2017;80:50-60.
https://doi.org/10.15388/Im.2017.80.11671

7. Lietuvos Respublikos baudžiamasis kodeksas. https://www. infolex.1t/portal/start_ta.asp?act $=$ doc $\& f r=$ pop\&doc $=66150$

8. Dikmen AH, Cankaya S. Associations between sexual violence and women's sexual attitudes, sexual self-consciousness, and sexual self-efficacy. J Interpers Violence 2020; 886260519897339.

9. Tyrimo ataskaita „Intymaus partnerio smurtavimo apraiškos Lietuvoje - moterų perspektyva“. Žmogaus teisių stebejimo institutas, 2018. http://hrmi.lt/tyrimo-ataskaita-intymaus-partnerio-smurtavimo-apraiskos-lietuvoje-moteru-perspektyva/

10. Krupskienė A., Narkauskaite L., Povilaitis R. ir kt. Smurto paplitimas ir jo prevencija Lietuvoje. Vilnius: Higienos institutas, 2011. https://www.hi.lt/uploads/pdf/leidiniai/Informaciniai/Smurto\%20paplitimas\%20ir\%20jo\%20prevencija $\% 20$ Lietuvoje.pdf

11. Risk and Protective Factors|Intimate Partner Violence|Violence Prevention|Injury Center|CDC 2020 https://www.cdc.gov/ violenceprevention/intimatepartnerviolence/riskprotectivefactors.html

12. Stonienė L., Aguonytė V., Narkauskaitė L. Smurto prieš moteris paplitimas ir priežastys. Visuomenès sveikata, 2012;2(57):8-15.

13. Lippy C, DeGue S. Exploring alcohol policy approaches to prevent sexual violence perpetration. Trauma Violence Abuse 2016;17(1):26-42.

https://doi.org/10.1177/1524838014557291

14. Tadros A, Sharon MJ, Hoffman SM, Davidov DM. Emergency department visits for sexual assault by emerging adults: is alcohol a factor? West J Emerg Med 2018;19(5):797-802.

https://doi.org/10.5811/westjem.2018.6.38219

15. Jina R, Thomas LS. Health consequences of sexual violence against women. Best Pract Res Clin Obstet Gynaecol 2013;27(1):15-26. https://doi.org/10.1016/j.bpobgyn.2012.08.012

16. Diskusijos „Tvirta mergaite““ vaizdo medžiaga. Psichika.eu 2015. https://psichika.eu/blog/diskusija-tvirta-mergaite-video/

17. Samarasekera U, Horton R. Prevention of violence against women and girls: a new chapter. Lancet 2015;385(9977):1480-2. https://doi.org/10.1016/S0140-6736(14)61775-X

18. Gevers A, Dartnall E. The role of mental health in primary prevention of sexual and gender-based violence. Glob Health Action 2014; 7:24741. https://doi.org/10.3402/gha.v7.24741

19. Rizkalla K, Maar M, Pilon R, McGregor L, Reade M. Improving the response of primary care providers to rural First Nation women who experience intimate partner violence: a qualitative study. BMC Womens Health 2020; 20(1):209.

https://doi.org/10.1186/s12905-020-01053-y

20. Kirelienè I. Socioedukacinis darbas išeivijos bendruomenèje (Social work in non - native land community). Tiltas $i$ ateitic, 2013;1(7): 41-45.

21. Messing JT, Thaller J, Bagwell M. Factors related to sexual abuse and forced sex in a sample of women experiencing 
police-involved intimate partner violence. Health Soc Work 2014;39(3):181-91.

https://doi.org/10.1093/hsw/hlu026

22. Tharp AT, DeGue S, Valle LA, Brookmeyer KA, Massetti GM, Matjasko JL. A systematic qualitative review of risk and protective factors for sexual violence perpetration. Trauma Violence Abuse 2013;14(2):133-67. https://doi.org/10.1177/1524838012470031

23. Hooper LM, L'Abate L, Sweeney LG, Gianesini G, Jankowski PJ. Models of psychopathology: generational processes and relational roles. Springer Science + Business Media 2014. https://doi.org/10.1007/978-1-4614-8081-5 https://doi.org/10.1007/978-1-4614-8081-5

24. Ahmad A, Aziz M, Anjum G, Mir F. Intimate partner violence and psychological distress: mediating role of Stockholm syndrome. Pak J Psychol Res. 2018;33:541-57.

25. Jewkes R, Fulu E, Tabassam Naved R, Chirwa E, Dunkle K, Haardörfer R, ir kt. Women's and men's reports of past-year prevalence of intimate partner violence and rape and women's risk factors for intimate partner violence: a multicountry cross-sectional study in Asia and the Pacific. PLOS Med 2017;14(9):e1002381.

https://doi.org/10.1371/journal.pmed.1002381

26. Breiding MJ, Basile KC, Klevens J, Smith SG. Economic insecurity and intimate partner and sexual violence victimization. Am J Prev Med 2017;53(4):457-64.

https://doi.org/10.1016/j.amepre.2017.03.021

27. Stylianou AM. Economic abuse within intimate partner violence: a review of the literature. Violence Vict 2018;33(1):3-22. https://doi.org/10.1891/0886-6708.33.1.3

28. Kearns MC, D'Inverno AS, Reidy DE. The Association Between Gender Inequality and Sexual Violence in the U.S. Am J Prev Med 2020;58(1):12-20.

https://doi.org/10.1016/j.amepre.2019.08.035

29. Oram S, Khalifeh H, Howard LM. Violence against women and mental health. Lancet Psychiatry 2017;4(2):159-70.

https://doi.org/10.1016/S2215-0366(16)30261-9

30. Mulder J, Teunissen TAM, Pranger ES, Hiddink-Til A, LagroJanssen ALM. Reporting after sexual violence: the influence of victim, assault and perpetrator characteristics. J Forensic Leg Med 2020;102076.

https://doi.org/10.1016/j.jflm.2020.102076

31. Michau L, Horn J, Bank A, Dutt M, Zimmerman C. Prevention of violence against women and girls: lessons from practice. Lancet 2015;385(9978):1672-84. https://doi.org/10.1016/S0140-6736(14)61797-9

32. Zollner H, Fuchs KA, Fegert JM. Prevention of sexual abuse: improved information is crucial. Child Adolesc Psychiatry Ment Health 2014;8:5.

https://doi.org/10.1186/1753-2000-8-5

33. Eogan M, McHugh A, Holohan M. The role of the sexual assault centre. Best Pract Res Clin Obstet Gynaecol 2013;27(1):47-58. https://doi.org/10.1016/j.bpobgyn.2012.08.010
34. Mangum DW. Intimate partner violence prevention programs in North Carolina. N C Med J 2016;77(6):398-401.

https://doi.org/10.18043/ncm.77.6.398

35. World Health Organization. Violence prevention: the evidence. 2013.

http://apps.who.int/iris/bitstream/10665/77936/1/978924150 0845 eng.pdf

36. O'Dwyer C, Tarzia L, Fernbacher S, Hegarty K. Health professionals' experiences of providing care for women survivors of sexual violence in psychiatric in patient units. BMC Health Serv Res 2019;19(1):839.

https://doi.org/10.1186/s12913-019-4683-z

37. Nahai F. "Me too" isn't just about somebody else. Aesthet Surg J 2018;38(10):1153-5.

https://doi.org/10.1093/asj/sjy173

38. Dickson S, Willis GM. Primary prevention of sexual violence in aotearoa New Zealand: a survey of prevention activities. Sex Abuse 2017;29(2):128-47.

https://doi.org/10.1177/1079063215583852

39. Ullman SE, Lorenz K, O'Callaghan E. Risk avoidance strategies after sexual assault: a dyadic study of survivors and informal support providers. Vict Offenders 2018;13(6):814-33. https://doi.org/10.1080/15564886.2018.1479910

\section{THE ANALYSIS OF REASONS AND PREVENTION OF SEXUAL VIOLENCE: LITERATURE REVIEW}

\section{A. Pozniak, N. Fatkulina}

Keywords: reasons of sexual violence, risk factors associated with sexual violence, prevention of sexual violence.

Summary

Sexual violence is a serious and unrecognizable problem in our society. Sexual violence can have psychological, physical and reproductive effects on a survivor. This kind of aggression is most commonly experienced from intimate partners and in many cases is accompanied with economic, physical and psychological violence. That is how women's fundamental rights to equality and dignity are violated. It is important to understand the main causes of sexual violence because only in this way we can reduce the prevalence of it.

The objective. The goal of this article is to review reasons and prevention of sexual violence.

Methods. We analysed publications using databases like PubMed, Cochrane, Google scholar. Certain keywords and their combinations were used to find specific articles.

Results and conclusions. The reasons for sexual violence should always be explored in complex not separately. The aggressor is usually aggressive, not able to resolve the conflicts, has a lack of education and child trauma. The compliance of victim to aggressor, the wishes to help aggressor cold be also evaluated as violence reasons. It is significant to use the three levels of prevention in order to prevent sexual violence.

Correspondence to: pozniakalisa@gmail.com

Gauta 2021-03-18 